\title{
Study on Construction of Hydrological Monitoring System of the Yangtze River and Application of New Technologies on Flood Monitoring
}

\author{
Junya MEI ${ }^{1}$, Bo ZHOU, Qiong WU \\ Bureau of Hydrology, Changjiang Water Resources Commission, Wuhan 430010 ,
} China

\begin{abstract}
The flood of the Yangtze River has the characteristics of high peak, large quantity and long duration. The Yangtze River Hydrology Bureau summarizes and combs the complete business process chain of flood hydrological monitoring, and gradually constructs the Yangtze River flood hydrological monitoring system. Including station network layout, early warning response, monitoring technology, information processing, results output and other dimensions. The hydrological monitoring system of the Yangtze River flood has been gradually constructed and has been successfully applied in many flood basins. Especially under the special situation of COVID-19 epidemic situation in 2020 and the severe flood situation in the Yangtze River Basin, the scientific and practical nature and practicability of the hydrological monitoring system of the Yangtze River flood are further verified. In view of the shortcomings existing in the existing monitoring system, this paper looks forward to the frontier technologies involved in flood monitoring, and has a certain reference function for flood hydrological emergency monitoring.
\end{abstract}

Keywords: The Yangtze River, the Yangtze River Economic Belt, flood, hydrological monitoring system, big data, Beidou satellite, GF satellite, Internet+

\section{Introduction}

The Yangtze River originates from the Geladandong Glacier on the Qinghai-Tibet Plateau and is the largest river in China. It flows through 11 provinces and cities, including Qinghai and Tibet, and finally into the East China Sea via Shanghai. The main stream is about $6,300 \mathrm{~km}$ long, and the basin area is about 1.8 million $\mathrm{km}^{2}$, accounting for $18.8 \%$ of China's land area. The Yangtze River system is composed of more than 7,000 tributaries, of which 8 tributaries have a catchment area of more than $80,000 \mathrm{~km}^{2}$, including the Yalong River, the Jialing River and the Wujiang River. At its middle-lower reaches, the main lakes are the Poyang Lake and the Dongting Lake [1].

The Yangtze River, which runs through the east and west of China, is known as the "Golden Waterway." In 2016, China established a new development pattern of "one axis, two wings, three poles and multiple points" of the Yangtze River Economic Belt. This Belt covers $21 \%$ of the land area, and its population and total economic output both 
exceed $40 \%$ of the whole country. Therefore, it has an important ecological position, strong comprehensive strength and huge development potential [2]. The "Yangtze River protection" is an important measure based on the strategy of the Yangtze River Economic Belt. It is very important for the development and construction of the Yangtze River Economic Belt to control floods of the Yangtze River.

The Yangtze River Basin is basically located in the East Asian subtropical monsoon area, most of which belong to the subtropical zone. There are many rainstorms in the Yangtze River Basin, and the rainstorm is widely distributed, and its flood is mainly caused by rainstorm. According to historical records, between 206 BC and 1911, 214 floods occurred in the Yangtze River, with an average of 10 years. In the middle of the 19th century, two major floods occurred in 1860 and 1870 in succession. There was a major flood about six years after 1911. The floods of 1931 and 1935 killed more than 140000 people. In 1954, the flood area flooded 3.17 million $\mathrm{hm}^{2}$, of cultivated land and killed more than 30, 000 people as a result of the disaster, and the Beijing-Guangzhou Railway was shut down for 100 days. Another flood occurred in 1998, in the upper and middle reaches of the Yangtze River in 2010, in the middle and lower reaches of the Yangtze River in 2016 and 2017, in the upper reaches of the Yangtze River in 2018 [3], in the middle and lower reaches of the Yangtze River in 2019, and in the Yangtze River in 2020. The flood of the Yangtze River has obvious regional characteristics, temporal and spatial characteristics and flood characteristics of high peak, large quantity and long duration. If we do not deal with it scientifically, it will cause serious flood and waterlogging disasters and seriously damage the safety of the lives and property of the people in the basin.

In order to successfully cope with the flood and ensure the sustainable development of the Yangtze River economic belt, it is necessary to control the flood reasonably through fine forecasting and dispatching. Taking the 2020 Yangtze River flood as an example, in mid-August, the main tributaries of Mintuo River and Jialing River in the upper reaches of the Yangtze River suffered seriously. The three Gorges Reservoir had the biggest flood since it became a reservoir, and the flood peak reached $75000 \mathrm{~m}^{3} / \mathrm{s}$ at 8 : 00 on the 20th. Through fine forecast, combined operation of reservoir group in the upper reaches of the Yangtze River, cumulative flood storage of 19 billion $\mathrm{m}^{3}$, and reduction of flood peak (flood volume) once in 90 years (130 years) to 20 years (40 years), the flood control pressure of the basin has been significantly reduced, the opening of Jingjiang flood diversion area has been avoided, and great benefits of flood control and disaster reduction have been brought into play [4]. In addition to hydrological prediction and water engineering dispatching technology, the high precision technology behind these successful cases can not only be separated from scientific, efficient and systematic hydrological monitoring technology. Hydrological monitoring system provides efficient and accurate data sources for forecasting and dispatching system, and through real-time feedback between front and rear, constantly optimize survey layout and result analysis and processing, and cooperate with each other to provide support for flood and drought disaster prevention. Through the monitoring practice of the Yangtze River flood, the hydrological monitoring system of the Yangtze River flood has been gradually formed.

\section{Construction of Hydrological Monitoring System of the Yangtze River on Flood Monitoring}

\subsection{Overall Architecture}

The hydrological monitoring system of the Yangtze River includes the station network layout, early warning and response, monitoring technology, information processing and 
result output, as shown in Figure 1.

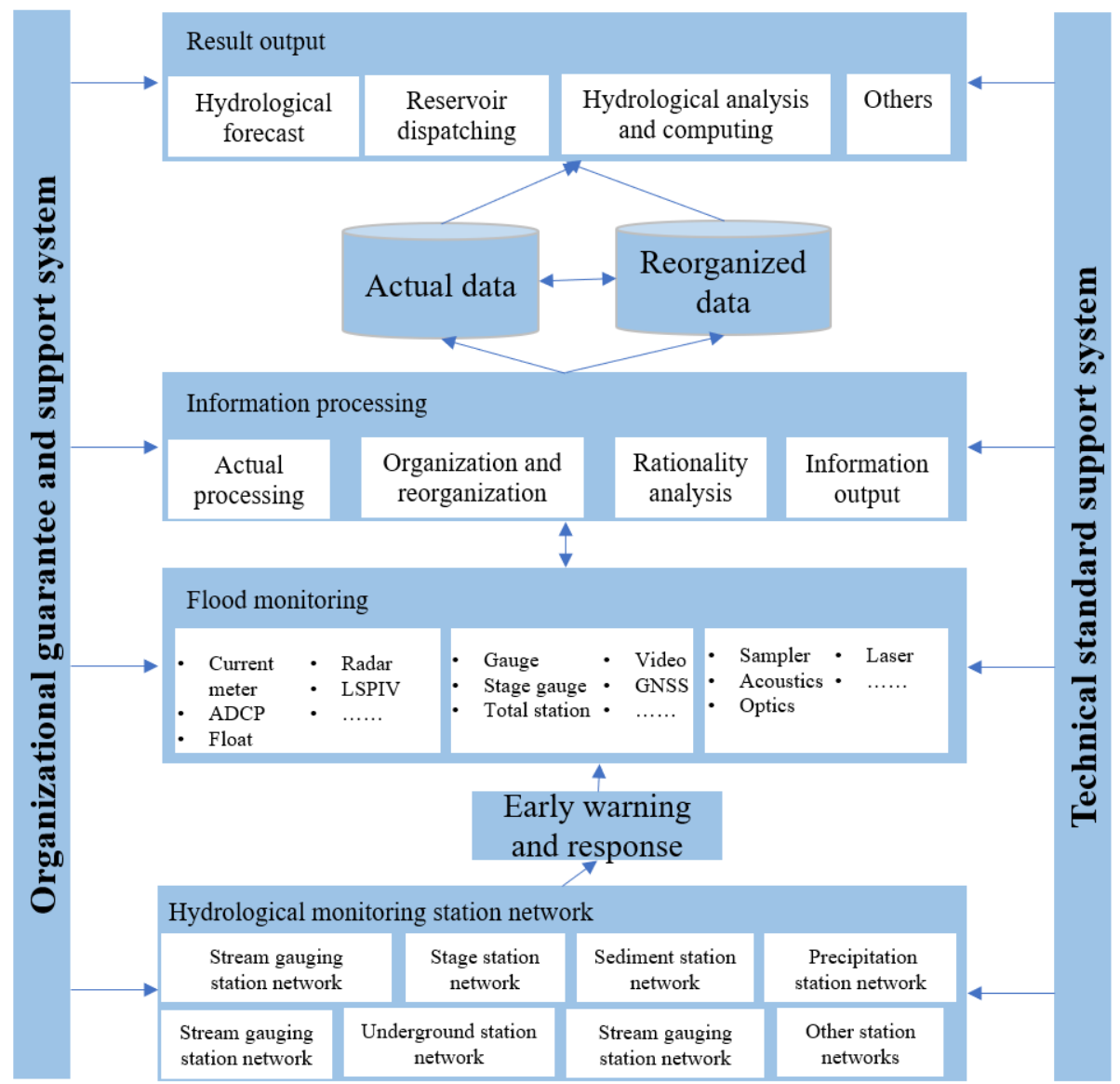

Figure 1. Structure diagram of flood monitoring system of the Yangtze River.

\subsection{System Components}

(1) Hydrological monitoring station network

The hydrological station network is the "workplace" of hydrologists. After four large-scale station network planning and adjustment in 1956, the Yangtze River Basin has formed the current station network system with reasonable structure and scientific layout [5]. The Yangtze River Hydrology has set up more than 300 hydrological monitoring stations at the important water system nodes such as the main stream of the Yangtze River and the main tributaries, and uses "clairvoyance" to control the water and rain of the Yangtze River in real time. At the same time, with the hydrological and meteorological departments of the provinces and cities in the basin, reservoir management departments, information sharing, the Yangtze River flood control forecasting and dispatching system has gathered 30,000 water and rain stations in the basin. 
(2) Early warning response

In addition to the requirements of Hydrologic Survey Assignment, a special early warning and response mechanism was set up as the driving factor to carry out flood monitoring of the Yangtze River. When the driving conditions of Regulations on Flood Numbering of Major Rivers in China, Regulations on Flood Numbering of Major TransProvincial Tributaries of the Main Stream of the Yangtze River from Shigu to Cuntan Section and the Basin and Emergency Plan for Flood and Drought Disaster Prevention in the Yangtze River Basin are satisfied, flood monitoring of the Yangtze River shall be carried out immediately.

(3) Monitoring technology

After many years of development, the Yangtze River Hydrology has formed a monitoring system of "combination of resident and patrol, priority of inspection and survey, automatic monitoring and reporting, emergency supplement" [6]. In the process of flood monitoring in the Yangtze River, in addition to the use of conventional monitoring technology, in recent years, it has gradually changed to non-contact and rapid monitoring means, and adopted the innovative model of multi-source data fusion to carry out monitoring and data rationality analysis and processing, so as to ensure the timeliness and accuracy of flood monitoring data. At present, according to the design concept of "one station, one policy", the Hydrological Emergency Forecast Plan of the Yangtze River Flood has been formulated to ensure the collection and submission of key elements such as water level and discharge in the event of severe floods. Recently, Beidou navigation satellite system, which has been successfully connected around the world, has also played an important role in flood control and disaster relief. As one of the core functions of Beidou, the short message function provides a guarantee for the transmission of key hydrological information in the harsh natural and network environment caused by heavy rain and flood in flood season.

(4) Information processing

The hydrological industry is a typical data production industry. Under the Bureau of Hydrology, nearly $80 \%$ of the hydrological stations have accumulated more than 30 years of continuous hydrological data and a large quantity of flood monitoring data. The big data analysis method is used to mine the value of historical hydrological monitoring data, and provide support for the arrangement of major flood times of measurement, the alignment of water stage-discharge relationship, and the corresponding discharge reporting. Relying on the model of "Internet + hydrological monitoring", tasks management, instrument calibration, hydrological survey, data compilation and other links are effectively connected in the form of information flow, providing support for the information processing of Yangtze River flood monitoring [7-8]. Based on the Yangtze River hydrological monitoring and management platform and the hydrological data online compilation system, information processing is completed, data is collected into the real-time database and compilation database, and standard API interfaces are made available for the Yangtze River flood control forecasting and dispatching system and other platforms.

(5) Result output

The results of flood monitoring are stored in the compilation database and real-time database, and provide basic data for hydrological forecast and hydrological analysis and calculation.

(6) Support system

The successful implementation, the organizational guarantee and technical standard system of Yangtze River flood monitoring play a very important role as a foundation 
support. The organizational guarantee covers work guarantee, traffic guarantee, communication guarantee, technical guarantee, emergency support guarantee, safety guarantee and training and drill guarantee, etc. The Technical Guidelines for Hydrologic Emergency Monitoring and other national and industrial technical standards guarantee the accuracy, rationality and suitability of the monitoring methods for large floods, and are an important means to ensure the quality of monitoring results.

\section{Practice of the Yangtze River Flood Monitoring in 2020}

The Bureau of Hydrology carried out hydrological monitoring over the Yangtze River flood under the support of the hydrological monitoring system of the Yangtze River.

\subsection{Monitoring Preparation}

The hydrological stations of the Yangtze River Hydrology Bureau have a wide range of lines. In the face of the 2020 epidemic situation of COVID-19 and the severe flood control situation, the Yangtze River Hydrology Bureau has always adhered to both the epidemic prevention and control and flood control work, adopted extraordinary methods to make preparations before flood; innovated and adopted the working mode of "selfinspection and field spot inspection", developed a three-level network self-inspection system to complete flood inspection and rectification. Timely compilation and release of the Yangtze River extraordinary flood hydrological emergency forecast plan, the whole river organized more than 20 actual flood control forecasting exercises, successfully completed the hydrologic bureau level super standard flood forecasting exercises, for the smooth implementation of the 2020 Yangtze River flood has made technical preparations.

\subsection{Overview}

In 2020, under the influence of concentrated heavy rainfall, a flood occurred in the Yangtze River. Since June, eight major floods have occurred in Wujiang River, Jialing River and the upper reaches of the Yangtze River. The gaochang station in Minjiang River has the biggest flood since the station was built in 1939; the Fushun station in Tuojiang River has the biggest flood since the station was built in 2001, which is the biggest flood since 1981; the Beibei station in Jialing River has the second largest flood since it moved to the station in 2007; and the second largest flood has occurred since the station was built in 1939 in the main stream of the Yangtze River. The largest flood has occurred since the completion of the three Gorges Reservoir, and the flood peak reached $75000 \mathrm{~m}^{3} / \mathrm{s}$ at 8: 00 on August 20, as shown in Table 1. 
Table 1. Basic data about the numbered floods of the Yangtze River and main tributaries in 2020.

\begin{tabular}{|c|c|c|c|}
\hline No. & Time & Flood situation & Cause \\
\hline $\begin{array}{l}\text { The } \\
\text { Wujiang } \\
\text { River } 1\end{array}$ & $\begin{array}{c}6-22 \\
15: 00\end{array}$ & $\begin{array}{l}\text { The water stage at the } \\
\text { Wulong Station rose } \\
\text { to } 193.08 \mathrm{~m}\end{array}$ & $\begin{array}{l}\text { Affected by the intensified heavy rainfall, the incoming water } \\
\text { increased rapidly }\end{array}$ \\
\hline $\begin{array}{l}\text { The } \\
\text { Jialing } \\
\text { River } 1\end{array}$ & $\begin{array}{r}8-12 \\
12: 00\end{array}$ & $\begin{array}{l}\text { Above the warning } \\
\text { water stage at the } \\
\text { Xiaoheba Station }\end{array}$ & $\begin{array}{l}\text { Affected by heavy rainfall and incoming water from the } \\
\text { upper reaches, incoming water from the Fujiang, Tuojiang } \\
\text { and Minjiang Rivers at the upper reaches of the Yangtze } \\
\text { River increased rapidly }\end{array}$ \\
\hline $\begin{array}{l}\text { The } \\
\text { Jialing } \\
\text { River } 2\end{array}$ & $\begin{array}{r}8-16 \\
13: 00\end{array}$ & $\begin{array}{l}\text { Above the warning } \\
\text { water stage at the } \\
\text { Xiaoheba Station }\end{array}$ & $\begin{array}{l}\text { Affected by heavy rainfall, incoming water from the Fujiang } \\
\text { River a tributary of the Jialing River at the upper reaches of } \\
\text { the Yangtze River increased rapidly }\end{array}$ \\
\hline $\begin{array}{l}\text { The } \\
\text { Yangtze } \\
\text { River } 1\end{array}$ & $\begin{array}{c}7-2 \\
10: 00\end{array}$ & $\begin{array}{l}\text { Incoming discharge } \\
\text { to the Three Gorges } \\
\text { Reservoir } 50,000 \mathrm{~m}^{3} / \mathrm{s}\end{array}$ & $\begin{array}{l}\text { Affected by heavy rainfall, incoming water from the main } \\
\text { stream of the Yangtze River, the Fujiang River and the Three } \\
\text { Gorges area increased rapidly }\end{array}$ \\
\hline $\begin{array}{l}\text { The } \\
\text { Yangtze } \\
\text { River } 2\end{array}$ & $\begin{array}{c}7-17 \\
10: 00\end{array}$ & $\begin{array}{l}\text { Incoming discharge } \\
\text { to the Three Gorges } \\
\text { Reservoir } 50,000 \mathrm{~m}^{3} / \mathrm{s}\end{array}$ & $\begin{array}{l}\text { Affected by heavy rainfall, incoming water from the main } \\
\text { stream of the Yangtze River and the Three Gorges area } \\
\text { increased rapidly }\end{array}$ \\
\hline $\begin{array}{l}\text { The } \\
\text { Yangtze } \\
\text { River } 3\end{array}$ & $\begin{array}{r}7-26 \\
14: 00\end{array}$ & $\begin{array}{l}\text { Incoming discharge } \\
\text { to the Three Gorges } \\
\text { Reservoir } 50,000 \mathrm{~m}^{3} / \mathrm{s}\end{array}$ & $\begin{array}{l}\text { Affected by heavy rainfall, incoming water from the main } \\
\text { stream of the Yangtze River, the Jialing River, the section } \\
\text { between the Xiangjiaba and Cuntan Stations, and the Three } \\
\text { Gorges area increased rapidly }\end{array}$ \\
\hline $\begin{array}{c}\text { The } \\
\text { Yangtze } \\
\text { River } 4\end{array}$ & $\begin{array}{l}8-14 \\
5: 00\end{array}$ & $\begin{array}{l}\text { Discharge at the } \\
\text { Cuntan Station } \\
\text { increased to } 50,900 \\
\qquad \mathrm{~m}^{3} / \mathrm{s}\end{array}$ & $\begin{array}{l}\text { Under the influence of heavy rainfall, floods above the } \\
\text { guaranteed stage occurred in Tuojiang River and Fujiang } \\
\text { River, and floods above the warning stage happened in the } \\
\text { Minjiang River and the section between Luzhou and Cuntan }\end{array}$ \\
\hline $\begin{array}{l}\text { The } \\
\text { Yangtze } \\
\text { River } 5\end{array}$ & $\begin{array}{l}8-17 \\
14: 00\end{array}$ & $\begin{array}{l}\text { Discharge at the } \\
\text { Cuntan Station } \\
\text { increased to } 50,400 \\
\qquad \mathrm{~m}^{3} / \mathrm{s}\end{array}$ & $\begin{array}{l}\text { Under the influence of heavy rainfall, floods above the } \\
\text { warning stage occurred in the tributaries the Minjiang River, } \\
\text { the Tuojiang River and The Jialing River, and floods above } \\
\text { the guaranteed stage happened in the Fujiang River }\end{array}$ \\
\hline
\end{tabular}

\subsection{Flood Monitoring}

Based on the flood hydrological monitoring system, the Bureau of Hydrology successfully dealt with the eight numbered floods in 2020, and completed the change process of hydrological elements such as water stage, discharge and sediment, which provided a solid support for hydrological forecast and hydrological analysis and calculation. Taking the discharge monitoring as an example, during the eight numbered floods, the 12 controlling water system nodes such as Cuntan, Yichang, Hankou, Jiujiang, Datong, Xiaoheba and Gaochang adopted Acoustic Doppler Current Profiler (ADCP), current meter method, floats method, electric flow meter method, and other methods to complement each other; from June to August, the discharge was measured in 
a total of 651 times (see Table 2). The times of measurement of ADCP, current meter method, floats method, and electric flow meter method accounted for $57 \%, 38 \%, 4 \%$ and $1 \%$ respectively. It can be seen that rapid discharge monitoring technologies such as ADCP became the main technical means of flood monitoring.

The discharge times of measurement of the stations related to the Yangtze River flood monitoring from June to August are shown in Figure 2. It can be seen from the figure that the total times of measurement of Cuntan Station are up to 78; According to the monthly distribution, there are 139 times in June, 240 times in July and 272 times in August, with the largest number in August, mainly due to the occurrence of 8 numbered floods in August, including 2 numbered floods in Jialing River and 2 numbered floods in Yangtze River. Taking Cuntan in the main stream of the Yangtze River as an example, in the five numbered floods, scientific times of measurement were arranged according to the station characteristics and flood change characteristics of Cuntan Hydrological Station, so as to completely control the discharge change process (see Figure 3).

Rational analysis shows that the water stage and discharge process of each station are corresponding, the process comparison of upstream and downstream stations is reasonable, the flood peak water stage and peak discharge time are corresponding, the water volumes of upstream and downstream are balanced, and the flood survey results are reliable. See Table 3 for the statistics of flood characteristic values of all relevant stations.

Table 2. Statistical data of discharge times of measurement at stations related to the Yangtze River flood from June to August in 2020.

\begin{tabular}{|c|c|c|c|c|c|}
\hline \multirow{2}{*}{ Observation station } & \multirow{2}{*}{ River } & \multicolumn{4}{|c|}{ Observation method } \\
\hline & & ADCP & Current meter & Float & Electric flow meter \\
\hline Gaochang & The Minjiang River & & 55 & 1 & \\
\hline Fushun & The Tuojiang River & & 71 & & \\
\hline Xiaoheba & The Fujiang River & 25 & & 23 & 8 \\
\hline Beibei & The Jialing River & & 52 & & \\
\hline Cuntan & The Yangtze River & 75 & 3 & & \\
\hline Wulong & The Wujiang River & & 58 & & \\
\hline Chenglingji & The Yangtze River & 61 & & & \\
\hline Yichang & Dongting Lake Waterway & 56 & 11 & & \\
\hline Hankou & The Yangtze River & 51 & & & \\
\hline Jiujiang & The Yangtze River & 35 & & & \\
\hline Hukou & Poyang Lake Waterway & 38 & & & \\
\hline Datong & The Yangtze River & 28 & & & \\
\hline
\end{tabular}


Table 3. statistical data of characteristic values from the related stations during the Yangtze River flood in 2020 .

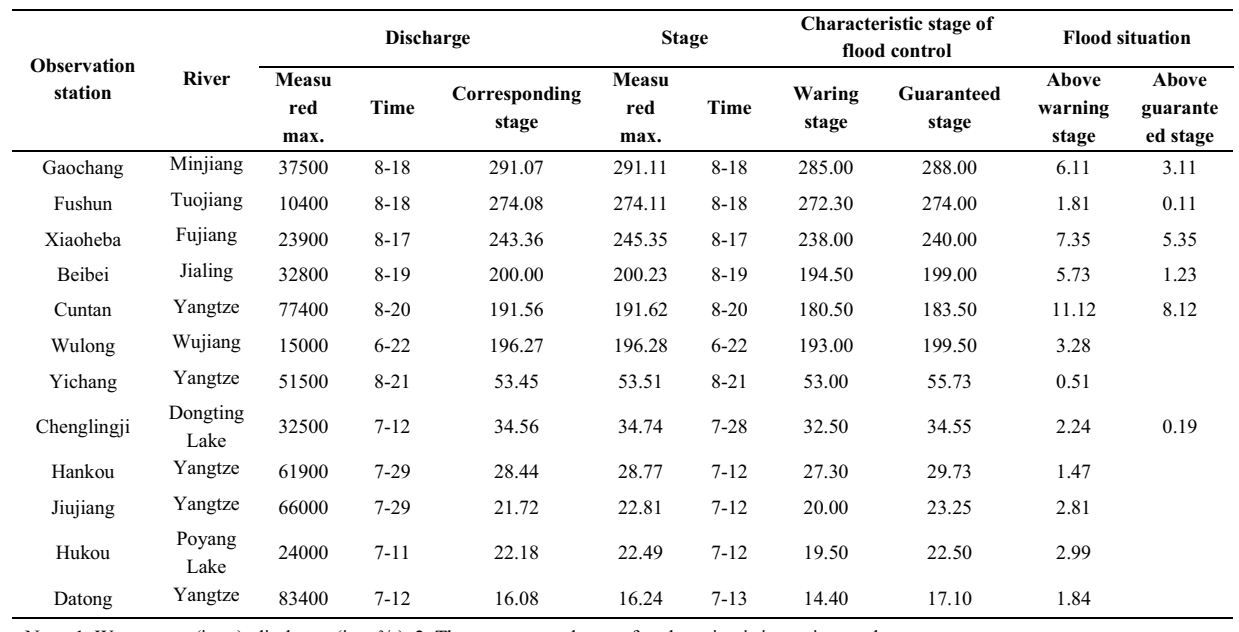

Note: 1 . Water stage (in $\mathrm{m}$ ), discharge (in $\mathrm{m}^{3} / \mathrm{s}$ ); 2 . The water stage datum of each station is its stationary datum.

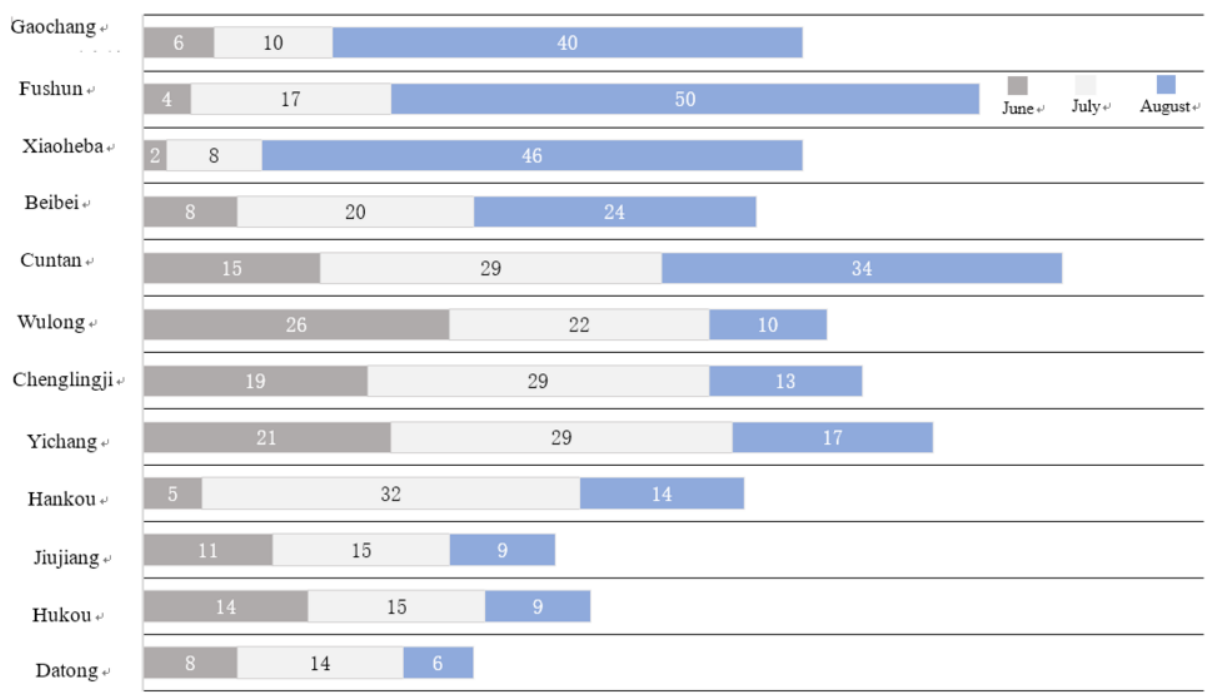

Figure 2. Diagram of discharge times of measurement distribution at stations related to the Yangtze River flood from June to August in 2020. 


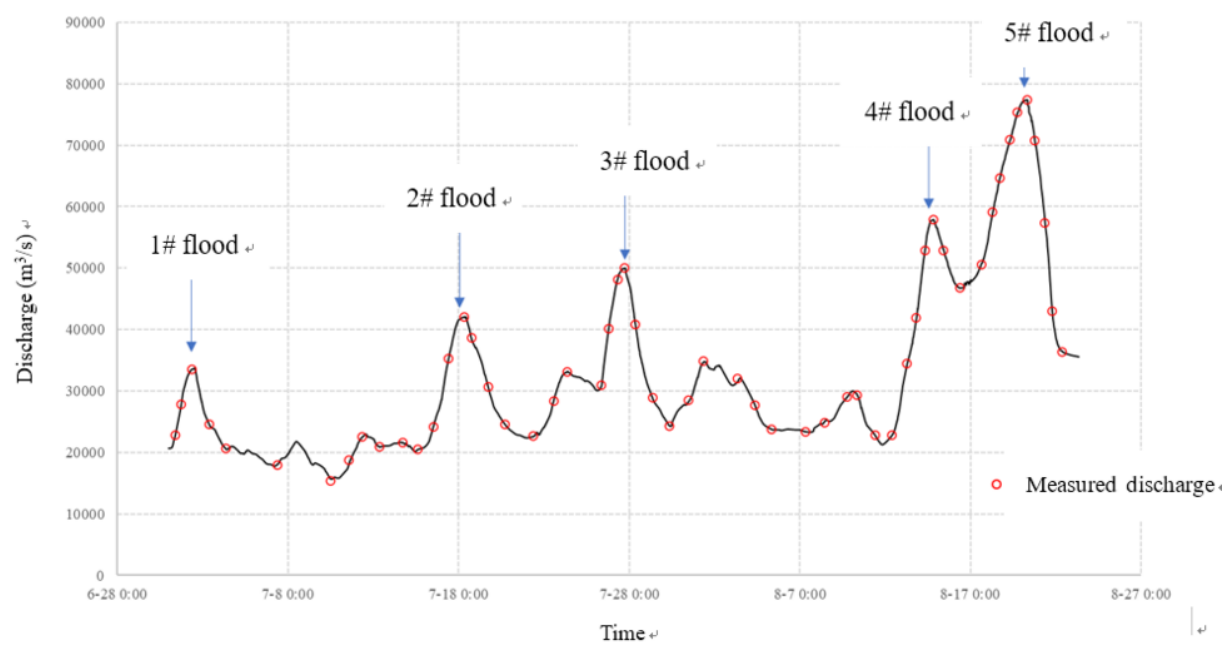

Figure 3. Diagram of times of measurement arrangement of Cuntan station discharge process control during 5 Yangtze River numbered flood in 2020.

\section{Conclusion}

In view of the characteristics of high peak, large volume and long duration of the Yangtze River flood, safeguarding the Yangtze River and controlling its floods is very important to develop and construct the Yangtze River Economic Belt. In order to cope with deluges successfully and guarantee the sustainable development of the Yangtze River Economic Belt, it is necessary to control them rationally through precise forecast and water dispatching. By continuous summarization and practice of monitoring over the previous floods in the Yangtze River, the Bureau of Hydrology has gradually established a scientific, efficient and complete Yangtze River flood hydrology monitoring system. This system can provide efficient and accurate data sources for the forecasting and dispatching systems to complement each other to provide support for prevention of floods and droughts. In the monitoring of many river basin floods, especially in the 8 numbered floods in 2020, it was successfully applied to collect continuous, reliable, complete water and sediment data. However, in the monitoring practice, some obvious weaknesses were also reflected, such as insufficient monitoring capacity, insufficient intelligence, and insufficient integration mechanism of various monitoring results. In order to further improve the hydrological monitoring system of the Yangtze River flood and enhance its monitoring capability and intelligence level, relevant research can be carried out in the following aspects:

(1) Study on the application of satellite remote sensing in flood monitoring. With the continuous development of satellite remote sensing technology, its time and space resolutions have been greatly increased. Satellite remote sensing data, combined with data of water level, flow rate and flow section from hydrological stations, can be used to carry out inversion model research based on supervised learning, such as satellite water level measurement and discharge computation, as well as quantitative accuracy 
evaluation, as an emergency supplement in case of severe floods where normal hydrological survey cannot be conducted by conventional means.

(2) Study on the application of machine learning in flood monitoring. The Bureau of Hydrology has collected a great deal of flood survey data. Therefore, the survey scheme can be continuously optimized based on machine learning algorithms such as Logistic Regression, Support Vector Machine and Random Forest, to research the most optimal strategy in survey method selection, vertical layout, measurement point selection and duration selection during the period of high flood, and continuously improve the intelligence level of flood monitoring.

\section{Acknowledgments}

This work is supported by National Key R \& D Program of China (2018YFC1508002).

\section{References}

[1] Encyclopedia of Rivers and Lakes in China Compilation Committee. Encyclopedia of Rivers and Lakes in China· The Yangtze River Volume (1st) [M]. Jan. 2010 1st version. China Water \& Power Press, 2010.

[2] Deng S, Mei JY, Zhou B et al. Research on hydrological emergency monitoring scheme and technology of Barrier Lake. IOP Conf. Ser.: Earth Environ. Sci. 2019, 344(2019):012102.

[3] Chen M. Construction and achievements of flood control, draught relief and disaster reduction systems in the Yangtze River Basin China. Flood \& Drought Management. 2019(10), 29:36-42.

[4] Cheng HY. Flood forecasting system its role in project networks China. Water Resources. 2020, 17: 11-3.

[5] He H. China gauging station network Advances in Water Science 2010, 21: 460-5.

[6] Wang J et al Modern Hydrologic Monitoring Technology [M]. Dec. 2016 1st version. China Water \& Power Press, 2016.

[7] Zhou B et al. Research and practice of "internet + hydrological monitoring" of the Yangtze River. IOP Conf. Ser.: Earth Environ. Sci. 2019, 344: 012104.

[8] Wang J. Research on the hydrological monitoring system of the Yangtze River based on "Internet+ [J]. Technology and Economy of Changjiang. 2018, 2:70-4. 